Indian Journal of Science and Technology

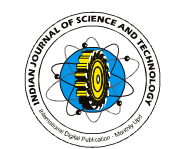

Vol. 5 No. 3 (Mar 2012)

ISSN: 0974- 6846

\title{
Complex 8;21 chromosome translocations formed by two step mechanism and simple 8;21chromosome translocation without $A M L 1$ gene involvement in acute myelocytic leukemia
}

\author{
Kimio Tanaka*, Masako Minamihisamatsu ${ }^{1}$, Taichi Kyo ${ }^{2}$ and Nanao Kamada ${ }^{3}$ \\ ${ }^{*}$ Department of Radiobiology, Institute for Environmental Sciences, Takahoko 2-121, Rokkasho, Kamikita, Aomori 039- \\ 3213, Japan \\ ${ }^{1}$ Radiation Hazards Research Group, National Institute for Radiological Sciences, Anagawa 4-9-1, Chiba 263-8555, \\ Japan \\ ${ }^{2}$ Fourth Department of Internal Medicine, Hiroshima Red Cross Hospital, Senda-machi, 1-9-6, Minami-ku, Hiroshima \\ 739-1743, Japan \\ ${ }^{3}$ Hiroshima Atomic Bomb Relief Foundation, 50-1, 3 Chome Asakita-ku, Hiroshima 739-1743, Japan \\ kmtanaka@ies.or.jp*
}

\begin{abstract}
As a result of reciprocal translocation between chromosomes 8 and 21, acute myelocyticleukemia (AML) cells contains chimeric gene of $A M L 1$ and MTG8/ETO and express fusion proteins. The AML $1-M T G 8 / E T O$ chimeric gene is considered to have an important role in the pathogenesis of AML FABM2. Among AML M2 patients, about $3-5 \%$ of the patients show complex translocation including chromosome 8;21 and third chromosome. We analyzed metaphases from seven AML M2 patients with complex 8;21 translocation by two color FISH using WCP probes, AML1 probe and several cosmid probes locating near AML1 and MTG 8/ETO locus. All of the 7 patients could show two step translocation (chromosome8-chromosome 21-third chromosome). Seven patients including two insertion 8;21 cases represented two step translocation for formation either between chromosome [der(8); 8q-] and third chromosome or between [der(8); 8q-]and [der(21); 21q+ ] chromosomes. These results suggest that there is at least two step mechanism for the formation of complex 8;21 translocation, following formation of standard 8;21 translocation and AML 1-MTG8/ETO chimeric gene. Interestingly, 3 patients diagnosed as AML FABM4, AML M2 transformed from myelodysplastic syndrome (MDS) (MDS-AMLM2) and acute lymphocytic leukemia (ALL) who had $t(8 ; 21)$ translocation had breakpoints proximal of $A M L 1$ gene. Other 13hematological disease such as AML or acute lymphocytic leukemia (ALL) patients who had chromosome abnormalities at band 21q22 of chromosome 21, including $t(16 ; 21)$ in 3 patients, had breakpoint at telomeric region of $A M L 1$. These results indicate that $21 \mathrm{q} 22$ chromosomal region has higher chromosome instability and is genetically extremely unstable.
\end{abstract}

Keywords: Complex chromosome translocation, acute myelocytic leukemia, chromosome instability, $A M L 1$ gene, FISH Introduction

Over $20 \%$ of acute myelocytic leukemia (AML) patient with French-American- British (FAB) classification M2 subtype have a characteristic chromosome translocation, which arises from a translocation between chromosomes 8 and 21 . Translocation $t(8 ; 21)$ is found in about $15 \%$ of patients with AML M2 (Bennett et al., 1985), in which it accounts for $40 \%$ of karyotypically abnormal cases (Fourth Internal Workshop on Chromosomes in Luekemia, 1984). It is most common translocation in AML and is characterized by a good prognosis and prolonged disease free survival. The $A M L 1$ (also called $R U N X 1$, $C B F 2 A$ ) oncogene, which is normally located at band $21 \mathrm{q} 22$ on chromosome 21 moves to the sites of the MTG8 (also called ETO, RUNX1T1, CDR) gene at band $8 \mathrm{q} 22$ on chromosome 8 as a consequence of the translocation (Miyoshi et al., 1993). The $\mathrm{t}(8 ; 21)$-positive AML is classified in a subtype of AML with recurrent genetic abnormalities (WHO Classification of Tumours, 2007). The 8:21 translocation-positive AML cells contain chimeric gene of $A M L 1$ and MTG8/ETO and express fusion proteins. The $A M L 1$ gene originally encodes a and activates gene expression. The AML1-MTG8/ETO chimeric gene on derivative chromosome 8 [der(8)] is considered to have an important role in the pathogenesis of AMLM2.Detection of the abnormality of the $A M L 1$ gene is important for diagnosis and disease management as response to well chemotherapy.

By conventional banding analysis, about $3-5 \%$ of the AMLM2 patients with $\mathrm{t}(8 ; 21)$ show complex translocation, which involves third or fourth chromosomes in additional to chromosomes 8 and 21 for the formation of complex 8;21 translocation (Sakurai et al., 1982; Fourth International Workshop on Chromosomes in Leukemia 1982, 1984; Groupe Francais de Cytogenetique Hematologique, 1990). No clinical differences have been noted between patients with standard 8;21 translocation and those with complex translocation (4th International Workshop on Chromosomes in Luekemia 1982, 1984; Kim et al., 2011). On the other hand, another molecular biological study indicated that the complex 8;21 translocations in AML were occurred by one step translocation or insertion of $A M L 1$ gene (de Greef et al., 1995; Taviaux et al., 1999; Vieira et al., 2001). These component (CBF alpha2; CBF2A), which binds to DNA

Research article

COIndian Society for Education and Environment (iSee)
"8;21 translocation in leukemia" http://www.indjst.org
Kimio Tanaka et al. Indian J.Sci.Technol. 
Table 1. Chromosome and FISH analyses in seven AML M2 patients with complex 8;21 karyotype, who had breakpoint in AML1 gene

\begin{tabular}{|c|c|c|c|c|c|c|c|c|c|c|c|}
\hline \multirow[b]{2}{*}{ 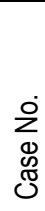 } & \multirow[b]{2}{*}{$\begin{array}{l}\text { শ } \\
\stackrel{\mathscr{D}}{0} \\
\stackrel{0}{0}\end{array}$} & \multirow[b]{2}{*}{ 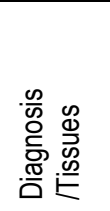 } & \multirow{2}{*}{ 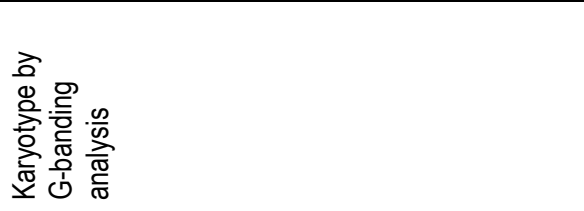 } & \multicolumn{7}{|c|}{ Interphase FISH analysis on AML1 gene } & \multirow[b]{2}{*}{$\begin{array}{l}\frac{r}{0} \\
\frac{1}{1} \\
\frac{1}{\alpha}\end{array}$} \\
\hline & & & & ¿'ర & 1 & 2 & 3 & 4 & 5 & 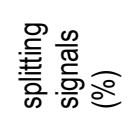 & \\
\hline 1 & $34 / M$ & $\begin{array}{l}\text { M2 } \\
\text { relapse } \\
\text { /BM }\end{array}$ & $\begin{array}{l}\text { 85, } X X,-Y, Y, \operatorname{del}(3)(p 13), t(8 ; 17 ; 21)(q 22 ; q 23 ; \\
\text { q22)x2, -9, add(9)(q34), -11, -16, -18 }\end{array}$ & 139 & 0 & 5 & 67 & 42 & 25 & 96.4 & ND \\
\hline 3 & $39 / \mathrm{F}$ & M2/ BM & $45, X,-X, t(1 ; 21 ; 8)(p 36 ;$ q22; q22), del(12)(p11) & 134 & 8 & 18 & 98 & 0 & 0 & 73.7 & ND \\
\hline 4 & $36 / M$ & M2/ BM & $45, X,-Y, t(8 ; 11 ; 21)(q 22 ; q 13 ; q 22)$ & 127 & 10 & 21 & 96 & 0 & 0 & 75.6 & ND \\
\hline 5 & $13 / F$ & M2/ BM & $46, X Y, t(8 ; 21 ; 17)(q 22 ; q 22 ; p 12)$ & 219 & 3 & 57 & 157 & 2 & 0 & 71.7 & + \\
\hline 6 & $74 / \mathrm{M}$ & M2/BM & $45, X,-Y$, ins $(21 ; 8)(q 22 ; q 22 q 23)$ & 103 & 3 & 13 & 87 & 0 & 0 & 84.5 & ND \\
\hline 7 & $44 / M$ & M2/BM & $46, X Y$, ins $(21 ; 8)(q 22 ; q 22 q 22)$ & 140 & 1 & 11 & 128 & 1 & 0 & 90.8 & + \\
\hline
\end{tabular}

Bone marrow samples were used for chromosome analysis. No case was performed in DNA rearrangement analysis on AML1 gene. Bold letter shows complex 8;21 aberrations. ND: not done; M2: AMLFABM2; BM: bone marrow; obs.: observed

previously obtained results prompted us a debate. Fluorescence in situ hybridization (FISH) method is powerful tool to identify precisely the chromosome aberrations.

To investigate the usefulness of FISH in disordering the mechanisms of origin and the second breakpoints involved in complex 8;21 translocations of rearrangement, we studied 7 patients with complex $8 ; 21$ translocation. Second breakpoint regions were located on either on derivative chromosome 21[der(21)] or chromosome 8[der(8)]. Second breakpoints seems to be always occurred at regions around first breakpoints of AML1, which always translocate to chromosome 8 or at near region of MTG8 gene on der(8) chromosome. This indicates that $21 \mathrm{q} 22$ region involving telomeric $A M L 1$ gene and MTG8 have genetically extremely unstable, involving possible chromatin remodeling mechanism. Then we analyzed other 13 patients diagnosed as AML or acute lymphocytic leukemia (ALL) who had 21q22 abnormalities by FISH using AML1 probe, including $t(8 ; 21)$ and $t(16 ; 21)$ in each 3 patient but they did not have $A M L 1$ gene rearrangement and had their breakpoints proximal of $A M L 1$ gene.

\section{Materials and methods}

Patients: Seven AML patients (4 males and 3 females) (case nos.1-7 listed in Table 1) were used for present study, who had complex 8;21 translocation. All of the patients had the typical and hematological features of $A M L F A B$ M2. In addition, another 13 hematological disease patients [5AML M2, 2 AML M4, 2 MDS-AML M2, 2 MDS (one each of refractory anemia (RA) and refractory anemia with excess blasts (RAEB), one each of ALLFABL1 and FABL2] (patients nos.8-20 in Table 3) who had chromosome abnormality at 21q22 region of chromosome 21 such as $\mathrm{t}(8 ; 21), \mathrm{t}(3 ; 21), \mathrm{t}(17 ; 21)$, $\mathrm{t}(16 ; 21)$, add(21)(q21) and iso-dicentric chromosome 21[idic(21)] were analyzed by FISH or real time polymerase chain reaction (RT-PCR).

Chromosome analysis: Chromosome analyses were performed by G- or Q banding method in 20 AML or ALL or MDS patients, including 7 AML M2 with complex 8;21 translocation, with diagnosis of $F A B M 2$ and so on at onset or at relapse stage. Bone marrow cells were separated by Ficoll-hypaque sedimentation and monoblastic cells were cultured for $24 \mathrm{~h}$. Chromosome preparations were prepared as standard method and pretreated according to the International System for Human Cytogenetic Nomenclature (ISCN, 2005).

RNA analysis:

RNA from 2 of the 7 patients with complex $t(8: 21)$ was analyzed by RT-PCR method using primers locating AML 1 exon 5 and MTG8 exon 2 and hybridized with oligonucleotide probes locating in the junction regions of 8;21 translocation (Kozu et al., 1993) to confirm AML1MTG8/ETO chimeric gene and FISH results.

FISH analysis:

All of the 20 AML or ALL patients' samples were analyzed by G-banding method last ten years. Stored fixative solutions (3:1 methanol and acetic acid) from bone marrow cells were used for FISH on metaphases and interphase cells. Fresh bone marrow cells were also used for interphase FISH method, in which samples were treated with fixative solution immediately after receiving sample. Prepared slide were treated with RNAase (100 $\mu \mathrm{g} / \mathrm{ml})$ for $1 \mathrm{~h}$ and treated by pepsine $(10 \mathrm{mg} / \mathrm{ml})$ for 10 min and fixed with formaldehyde before hybridization. Each labeled 150-300 ng probe was mixed, denatured for 5 minutes and hybridized with $70 \%$ of formamide solution in moisture chamber for 48-72h.

For observation and photograph with dual colors simultaneously under fluorescence microscopy (Olympus TA325). For microphotograph, Fujichrome 400 was used adjusted as ASA 800. For analysis 8;21 translocation probes, in which biotin labeled AML1YAC mixture probes (cY3 and cY8)and 812 f2 YAC probe locating on 3' and 5'AML1 locus, respectively(courtesy from Dr. Ohki M. Japan Natl. Cancer Inst.) (Eguchi-Ishimae et al., 1998), and several cosmid or YAC probes locating on 21q21, 21q22and 8q22, D8S7 (obtained from Japan Gene Resource Bank), D21S65 locating centromeric portion
Research article

CIndian Society for Education and Environment (iSee)
"8;21 translocation in leukemia" http://www.indjst.org
Kimio Tanaka et al. Indian J.Sci.Technol. 
from AML1 locus, D21S75R (both were obtained from Japan Gene Resource Bank), three P1clone probes (T1420,T184 and T510) which are span LA68 and LL233 and involving D21S24 (courtesy from Dr. Ohki M. Japan Natl. Cancer Inst.), locating in order from centromere to telomere at the region proximal from AML1 locus of 21q22 (Ichikawa et al., 1993), and two cosmid probes locating on 21q22, mixture probe of D21S259, D21S341 and D21S342 locating on 21q22.13-22.2 (obtained from OncoSci, Gaitherburg, MD, USA), which are located on the region mapped for a candidate gene associated with Down's syndrome, were used for precise identification of breakpoint regions secondary occurred for the formation of complex $8 ; 21$ translocations or occurred outside of AML 1 gene by metaphase FISH. Biotin labeled AML1 YAC mixture probes (cY3 and $\mathrm{cY} 8$ ) were also used for interphase FISH to observe splitting signals on nucleus, indicating $A M L 1$ gene rearrangement. These probes covers from exons 5 to 7 of $A M L 1$ gene, which can identify $\mathrm{t}(8 ; 21)$ and $\mathrm{t}(3 ; 21)$ and others (Kawano et al, 1997; Tanaka et al., 1999a). The 200-250 interphase cells were scored to estimate the frequencies of splitting signals of AML1 in leukemic cells in each patient. For the interphase nucleus FISH, cut-off values of more than $4.13 \%$ (mean \pm 2 standard deviation)of AML1 signal in all of observed cells in each patient was used for classification as 8;21 translocation positive (Tanaka et al.,1999a,b). Biotin labeled AML1 probe was detected by avidin-fluorescein (FITC) (Vector, Mannheim, Germany). These other probes was also detected by avidinfluorescein (FITC) (Vector, Mannheim, Germany) or antidigoxygenin-TRITC (Berlinger Mannheim, Germany) after hybridization to view as green and red signals, respectively. In separate experiment, whole chromosome painting probes of chromosome 8 (WCP8) (Imagenetics, USA) and chromosome 21 (WCP21) (Onco Science Inc., Gaitherburg, MD, USA) were also used in mixture conditions for the analysis of chromosome translocation. Whole painted chromosomes 8 and 21 were directly observed as red and as green by staining with avidinFITC (Vector, Mannheim, Germany), under the fluorescence microscope, respectively. Site specific and painted chromosomes 8 and 21 were washed slightly by $2 x S S C$ solution for 10 minutes. The solution of 4,6diamino-2-phelindole-duhydrochloride (DAPI) (Sigma, St. Louis, USA) were used for the counter staining.

\section{Results}

Chromosome, FISH and RNA analyses on AML patients with complex $t(8 ; 21)$

Summary of chromosome and FISH analyses on AML patients with complex $t(8 ; 21)$ are shown in Table 1 in addition to the results of RNA analysis. Conventional Gbanding analysis revealed 5 patients had abnormalities of complex 8;21 translocation and 2 patients had insertion $8 ; 21$ in bone marrow cells in almost all metaphases. Five patients (nos.1-5) had a third chromosome such as chromosomes 17, 1 and 11 involving for 8;21 translocation. A patient (no.1) had tetraploid chromosomes with modal number of chromosome as 85 and complex $t(8 ; 17 ; 21)$. Chromosome 17 was found in 3 patients (nos. 1, 2 and 5), although their breakpoints on the chromosome 17 were variable. Interestingly two patient (nos.6 and 7) had ins $(21 ; 8)$, which showed two normal like chromosome 8 and one long $21(21 q+)$ chromosome. In both cases, a large region on chromosome 8 seemed to be inserted into chromosome 21. Representative karyotype of two patients (case nos.2, and 6 ) are shown in Fig.1. All of them had splitting signals of AML1, which had 3 or more signals on interphase nuclei by interphase FISH using $A M L 1$ gene probe, which indicate all the 7 patients had breakpoint of $\mathrm{t}(8 ; 21)$ was a $A M L 1$ gene region. Seven patients were analyzed by FISH on interphase nuclei, who had $71.7 \%$ to $96.4 \%$ of three signals of AML1 signals on interphase cells. Two patients (nos. 5 and 7) analyzed by RT-PCR method were confirmed to have AML1-MTG8/ETO chimeric gene, which showed a typical genetic features of $\mathrm{t}(8 ; 21) \mathrm{AML}$.

\section{Fig. 1. Representative G-banding karyotype of two AMLM2 patients including two complex 8;21 translocation} (case no. $2(A)$, and case no. $3(B)$
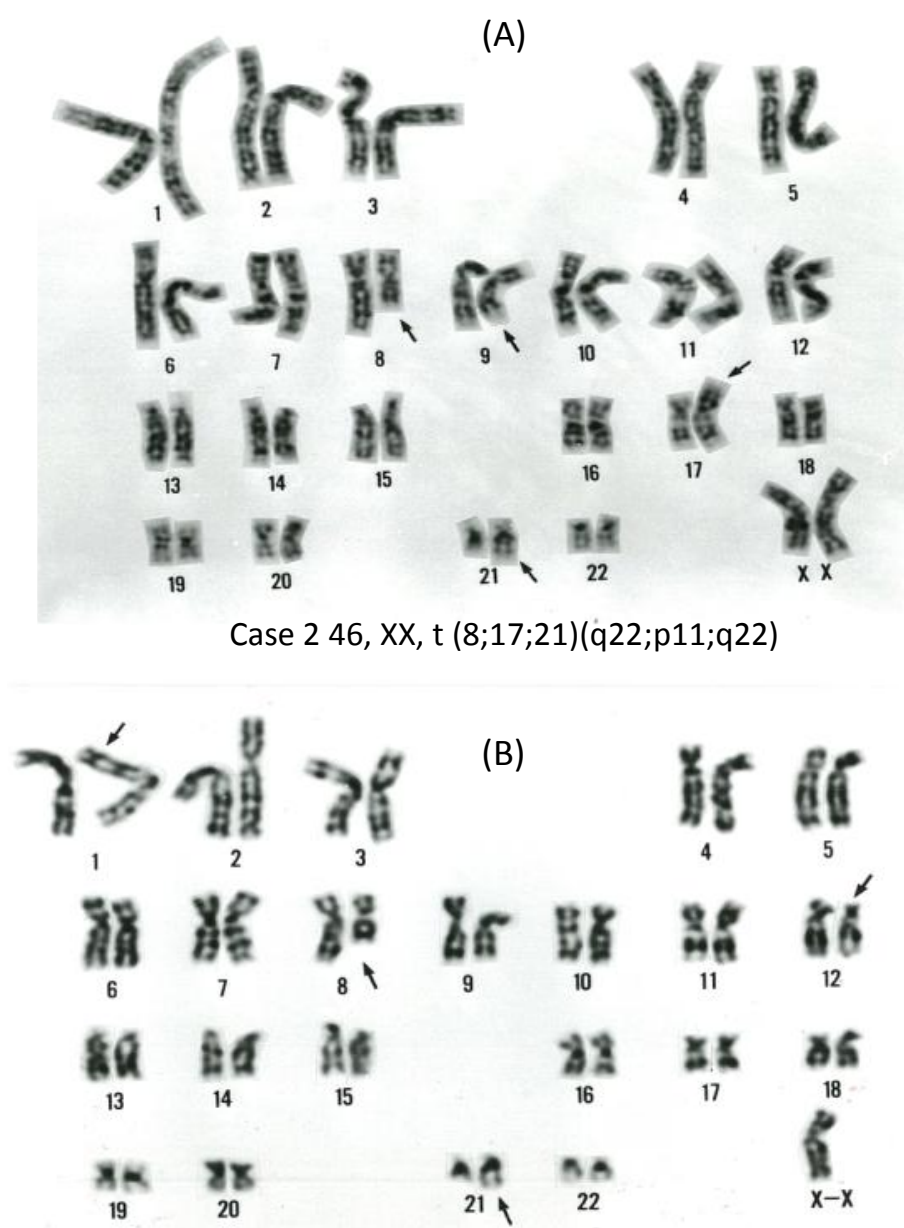

Research article

CIndian Society for Education and Environment (iSee)
"8;21 translocation in leukemia" http://www.indjst.org
Kimio Tanaka et al. Indian J.Sci.Technol. 
Indian Journal of Science and Technology

Fig.2. Scheme of complex t 8,21 translocations in five AMLM2 patients (case nos. 1-4) and one insertion 8;21(case no.6), which were analyzed by WCP8 andWCP21 and AML 1 probes

Case 1

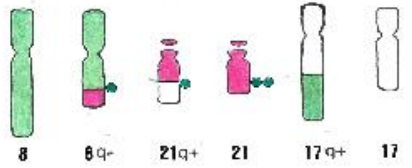

Case 2
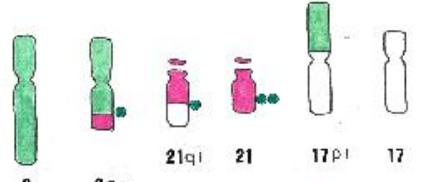

$t(8 ; 17 ; 21)$
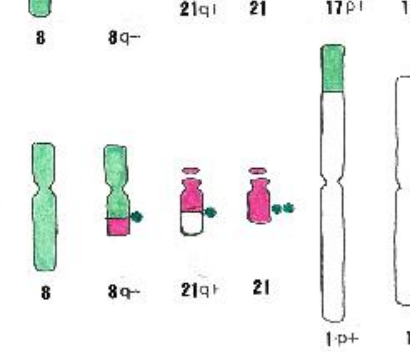

Case 4

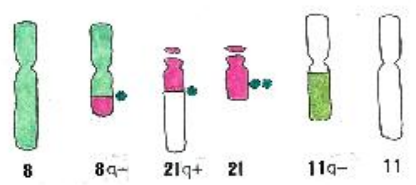

Case 6

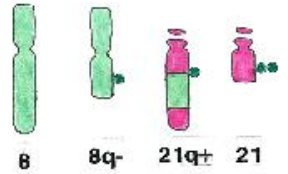

ins $(21 ; 8)$
Vol. 5 No. 3 (Mar 2012)

ISSN: 0974- 6846

Summary of FISH results in whole painting probes and AML1, YAC probe locating on chromosome 21 in five AMLM2 patients is shown with schemes in Fig.2. Whole painting probes (WCP 8 and WCP21) were painted normal chromosomes 8 and 21 as red and green, respectively, and terminal parts of $\operatorname{der}(8)$ chromosome was painted in green, but the terminal part of $\operatorname{der}(8)$ chromosome was not seen in green color because the end of painted chromosome 8 is not usually visible. Patient nos. 1, 2, 3, 4 and 5 showed same pattern in which derivative chromosome [der(8)] chromosome and one normal chromosome 8 were stained as red and derivative chromosome 21[der(21)], normal chromosome 21 and third chromosomes associating with complex 8;21 translocation were stained in green, although chromosome numbers of the third chromosomes associating complex 8;21 translocation were variable (Fig.2). A part of chromosome 21 always moved to $\operatorname{der}(8)$ chromosome (shown as 8q- in Fig.2) in patients(nos. 1-5) with complex 8;21 translocation, same as standard type $\mathrm{t}(8 ; 21)$. In standard $8 ; 21$ translocation, $A M L 1$ gene signals were localized on normal chromosome 21, and split on the der(8) and der(21) chromosomes. Splitting signals always locates on both $\operatorname{der}(8)$ and $\operatorname{der}(21)$ chromosomes in standard or simple $8 ; 21$ translocation. Splitting signals were always located on $\operatorname{der}(8), \operatorname{der}(21)$ (shown as 8q- and 21q+in Fig.2, respectively) and another overlapped larger signal on remaining one normal homologue chromosome 21. A part of chromosome 8 always moved to third chromosome, in which moved to chromosome 17 in 3 case (nos. 1, 2 and 5), and to chromosomes 1 and 11 in each one case (nos. 3 and 4 , respectively). The direction of movement of each chromosome segment of chromosomes 8 and 21 showed a quite consistent rule in these complex 8;21 translocations. Furthermore, the two patients (nos. 6 and 7) had interesting results, in which regions painted by red and green were arranged tandem on third chromosome, der(21). In the two insertion cases, apart of chromosome 8 moved to the middle region of der(21) chromosome, which became longer chromosome 21 (shown as 21q+in Fig.2). AML1 signals located on both $\operatorname{der}(8)$ and der(21) chromosomes. Representative FISH stained metaphases are shown in Fig. 3 .

$N D$ :not done *Second translocation was classified into 4 types on the basis of that in which region the second breakpoint localized, as shown in Fig.4. * * der(a); any third chromosome shown in Fig.4.

Research article

CIndian Society for Education and Environment (iSee)
"8;21 translocation in leukemia" http://www.indjst.org
Kimio Tanaka et al. Indian J.Sci.Technol. 


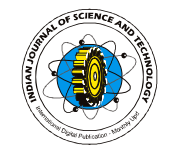

Fig.3.(A) Representative FISH stained metaphase in three patients with complex 8;21 translocation using WCP8 and WCP21 probes (case nos. 2 and 4), and (B) using AML 1 probe (case no. 1). Case 1 showed near tetraploid chromosomes. AML 1 signals were observed in both der(8) and der(21) chromosomes.(C) FISH stained metaphase of insertion 8;21 patient (case no.6) using WCP8 and WCP 21 probes.

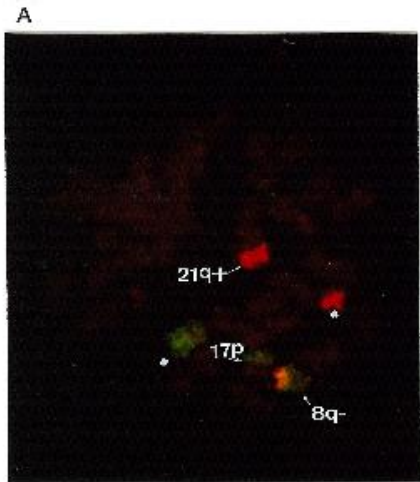

C a $s$ e 2

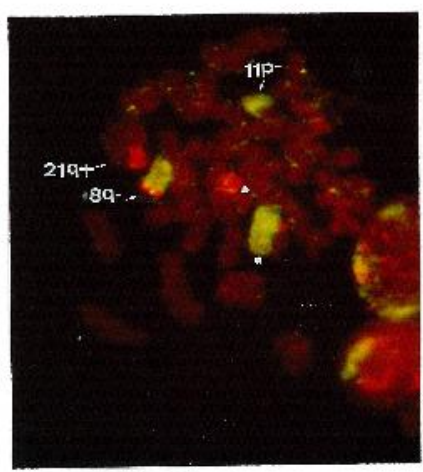

Cia s e 4

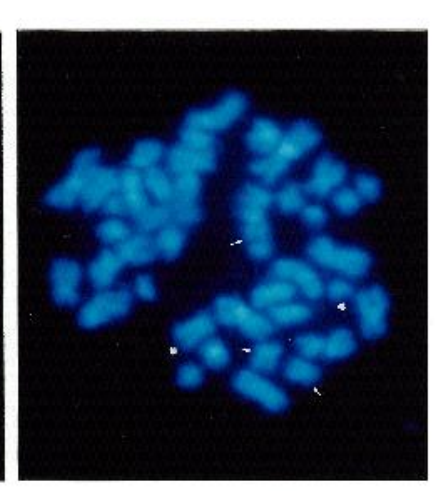

$(8 ; 17 ; 21)(q 22 ; p 11 ; q 22)$

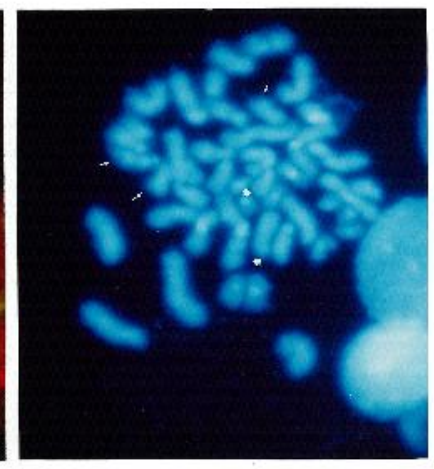

t. $(8 ; 11 ; 21)(q 22 ; q 13 ; q 22)$
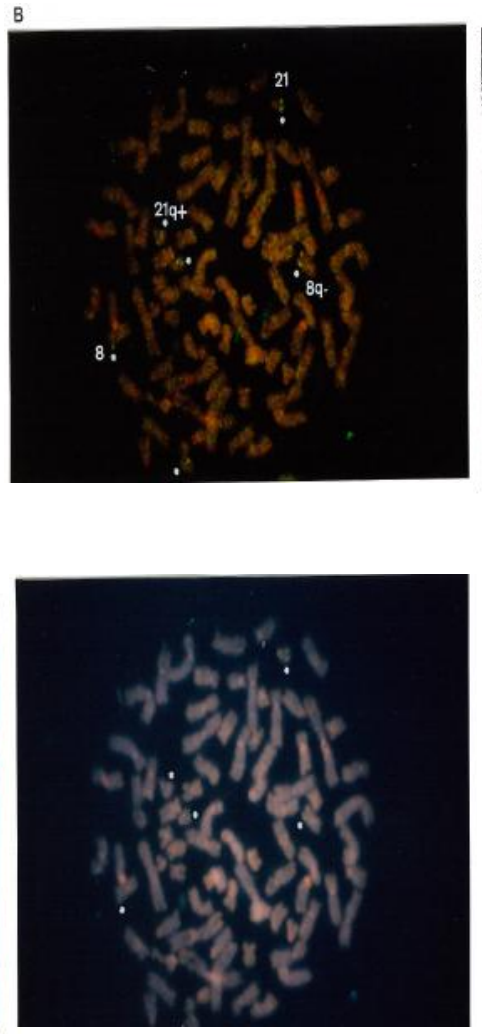

Case1 t $(8 ; 17 ; 21)$

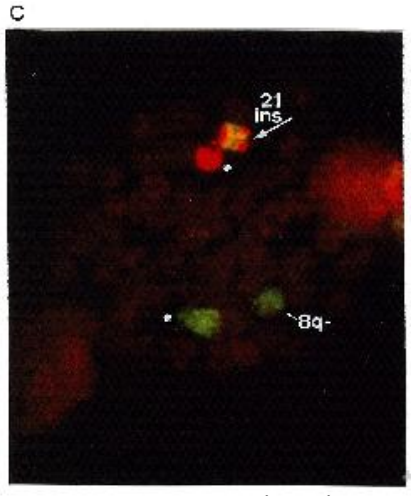

Case 6 ins $(8 ; 21)$

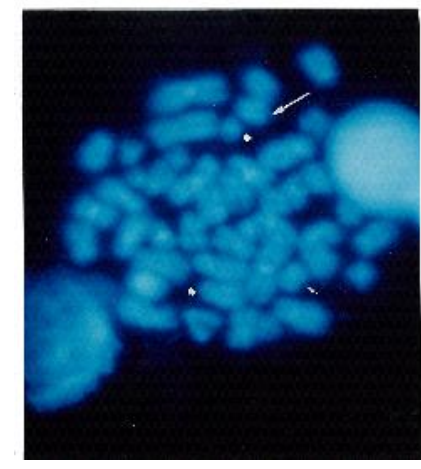
patients had second breakpoint in category in $D$, and the
2 patients (nos. 4 and 5 ) in category $C$. These results again strongly indicated that complex 8;21 translocation might be developed by two step translocation (Fig.5).

In another two patients (nos. 5 and 6) with insertion 8;21, D8S7and D21S75R were located on $\operatorname{der}(8)$ and der(21), respectively, which suggested that second breakpoint site might be between AML1 and D21S75R on der(21) chromosome. At this point we could not finally conclude which mechanism of one way or two way could be associated with these aberrations. However, the results of that D8S7 signal located on $\operatorname{der}(8)$, and while D21S75R signal on der(21) by the FISH observation in the two patients harboring insertion $8 ; 21$ could be also explained by two step mechanism, in which second translocation might be occurred between $\operatorname{der}(8)$ and der(21) after standard 8;21 translocation (Fig.6). Expression of AML1-MTG8/ETO chimeric gene was confirmed by RT-PCR method in one patient (case no.7), whose RNA sample was available. AML-MTG8 /ETO chimeric gene may locate on der(8) chromosome same as those of other complex $8 ; 21$ as well as standard $8 ; 21$ translocations. three patients (nos 1-3). Two patients (case nos 4 and 5) had signals of D8S7 and D21S75R on der(21) and der(8) chromosomes, respectively. Then it seems that the 3

Research article

CIndian Society for Education and Environment (iSee)
"8;21 translocation in leukemia" http://www.indjst.org
Kimio Tanaka et al. Indian J.Sci.Technol. 
Table 3. Chromosome and FISH analyses on 13 cases with 21 22 abnormalities who had breakpoints telomeric of $A M L 1$ gene

\begin{tabular}{|c|c|c|c|c|c|c|}
\hline \multirow{2}{*}{$\begin{array}{l}\text { Case } \\
\text { No. }\end{array}$} & \multirow[t]{2}{*}{ Sex } & \multirow[t]{2}{*}{ Age } & \multirow{2}{*}{$\begin{array}{l}\text { Disease/ } \\
\text { Tissues }\end{array}$} & \multirow{2}{*}{$\begin{array}{l}\text { Karyotype by G-banding } \\
\text { analysis }\end{array}$} & \multicolumn{2}{|c|}{ FISH analysis in $A M L 1$ gene } \\
\hline & & & & & $\begin{array}{l}\text { splitting } \\
\text { signal (\%) }\end{array}$ & Breakpoint region \\
\hline 8 & $\mathrm{~F}$ & 60 & $\begin{array}{l}\text { AML M4/ } \\
\text { Cell line }\end{array}$ & $\begin{array}{l}46, X X, t(8 ; 21)(q 22 ; q 22) \\
t(9 ; 22)(q 34 ; q 11)\end{array}$ & N.D. & $\begin{array}{l}\text { telomeric } \\
m B C R(\mathrm{R}+)\end{array}$ \\
\hline 9 & $\mathrm{M}$ & 64 & $\begin{array}{l}\text { MDS } \rightarrow \text { AML } \\
\text { M2/ BM }\end{array}$ & $\begin{array}{l}\text { 46, } \mathrm{X},-\mathrm{Y},-4,+8, \mathrm{t}(8 ; 21)(\mathrm{q} 22 ; \\
\text { q22), +del(21)(q22)/51, } \mathrm{X},-\mathrm{Y}, \\
\quad+5,+6,+7, \operatorname{der}(8) \mathrm{t}(8 ; 21)(\mathrm{q} 22 ; \\
\text { q22)x2, +i(8)(q10), -11, -13, - } \\
\text { 14, -17, -19, +20, +19, } \\
\text { +der(21)t(8;21)(q22; q22), } \\
\quad+\operatorname{der}(?) \mathrm{t}(? ; 21)(? ; \mathrm{q} 21)\end{array}$ & & $\begin{array}{l}\text { telomeric } \\
21 \mathrm{q} 22 \mathrm{SJT}(+)\end{array}$ \\
\hline 10 & $\mathrm{~F}$ & 8 & AML L1/ BM & $\begin{array}{l}\text { 46, XX, t(5;6)(q13;q21), } \\
\text { t(8;21)(q22;q22)/ idem. } \\
\text { der(21)t(8;21)(q22;q22) }\end{array}$ & $0 \%$ & telomeric TEL ( $\mathrm{R}-$ ) \\
\hline 11 & $\mathrm{M}$ & 58 & $\begin{array}{l}\mathrm{ALL} \text { M2, } \\
\text { relapse/ BM }\end{array}$ & $\begin{array}{l}\text { *46, XY, t(2;11)(q37; q14), t(17; } \\
\text { 21)(q11; q22)/47, XY, t(2; } \\
\text { 11)(q37; q14), t(17; 21)(q11; } \\
\text { q22), +mar }\end{array}$ & $0.6 \%$ & $\begin{array}{l}\text { Telomeric } \\
E R G(\mathrm{R}-)\end{array}$ \\
\hline 12 & $F$ & 13 & AML M2 /BM & $\begin{array}{l}46, X X, t(1 ; 21 ; 3)(p 35 ; q 22 ; \\
\text { p14)/47, idem. +4 }\end{array}$ & $2.3 \%$. & telomeric \\
\hline 13 & $\mathrm{~F}$ & 59 & $\begin{array}{l}\operatorname{MDS}(\mathrm{RA}) / \\
\mathrm{BM}\end{array}$ & $\begin{array}{l}46, \mathrm{XX}, \mathrm{t}(3 ; 21)(\mathrm{q} 25 ; \mathrm{q} 22), \mathrm{t}(3 ; \\
\text { 18)(p21; q23), del(5) } \\
\text { (q13q15)/46, XX, t(3; 18)(p21; } \\
\text { q23), del(14)(q24)/46, XX }\end{array}$ & N.D. & telomere \\
\hline 14 & $\mathrm{~F}$ & 23 & AML M2 /BM & $\begin{array}{l}\text { 46, XX, t(16; 21)(p11; q22)/46, } \\
X X, \mathrm{t}(16 ; 21)(\mathrm{p} 11 ; \mathrm{q} 22), \mathrm{t}(13 \\
\text { 18)(q14; } 11)\end{array}$ & $3.3 \%$ & telomeric \\
\hline 15 & $\mathrm{~F}$ & 24 & $\begin{array}{l}\text { AML M4, } \\
\text { relapse/ BM }\end{array}$ & $\begin{array}{l}46, X X, \operatorname{der}(8) t(1 ; 8)(p 11 ; p 23) \\
\text { t(16; 21)(p11; q22)/46, XX }\end{array}$ & N.D. & telomeric \\
\hline 16 & M & 43 & ALL L2 / BM & $46, \mathrm{XY}, \mathrm{t}(16 ; 21)(\mathrm{p} 11 ; \mathrm{q} 22)$ & N.D. & telomeric \\
\hline 17 & $\mathrm{~F}$ & 31 & $\begin{array}{l}\text { MDS(RAEB)/ } \\
\text { BM }\end{array}$ & $46, X X, \operatorname{add}(21)(q 22)$ & N.D. & telomeric \\
\hline 18 & $\mathrm{M}$ & 58 & $\begin{array}{l}\mathrm{AML} \mathrm{M} 2, \\
\text { relapse /BM }\end{array}$ & $\begin{array}{l}46, X Y, t(7 ; 11)(p 15 ; p 15) / 46 \\
X Y, \operatorname{del}(2)(p 21), t(7 ; 11)(p 15 \\
p 15), \operatorname{del}(9)(p 13), \operatorname{add}(21)(q 22)\end{array}$ & N.D. & telomeric \\
\hline 19 & $\mathrm{~F}$ & 78 & $\begin{array}{l}\text { AML M2 I } \\
\text { BM }\end{array}$ & $\begin{array}{l}50, X X, \text { del(5)(q13q32), } \\
\text { add(21)(q22), idic(21)(q22)x3, } \\
+22\end{array}$ & N.D. & $\begin{array}{l}\text { telomeric } \\
21 \mathrm{q} 22 \mathrm{SJT}(+)\end{array}$ \\
\hline 20 & $\mathrm{M}$ & 59 & $\begin{array}{l}\text { MDS } \rightarrow \text { AML } \\
M 2 / B M\end{array}$ & $\begin{array}{l}49, \mathrm{XY}, \text { del(5)(q31), } \\
\text { idic(21)(q22)×3 }\end{array}$ & N.D. & $\begin{array}{l}\text { telomeric } \\
21 \mathrm{q} 22 \mathrm{SJT}(+)\end{array}$ \\
\hline
\end{tabular}

*Karyotype at diagnostic stage showed 45, $X,-Y, t(8 ; 21)(q 22 ; q 22)$ and AMI-1-MTG8/ETO chimeric gene expression. Different clone was observed at relapse stage; N.D. $=$ Not done. 
Fig. 4. Metaphase FISH analyses using several cosmid, YAC and PAC probes located near AML 1 and MTG8(ETO) genes revealed which chromosome of der(8) or der(21) or der(a) may have second breakpoint site. Mechanism for complex 8;21 translocation was classified into four types of as $A, B, C$ and $D$ using the results on the assumption that a complex translocation is formed by two step mechanism. $\alpha$ is any number of third chromosome.

$$
\mathrm{t}(8 ; 21)
$$
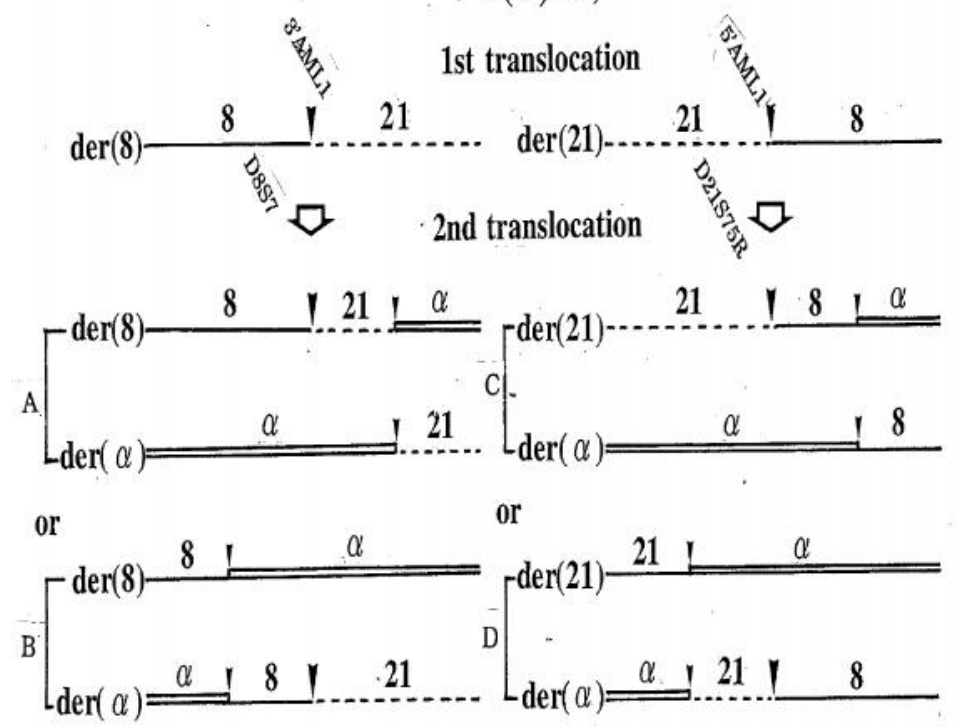

Fig.5.Scheme of two step model for formation of complex 8;21 translocation

Two step translocation

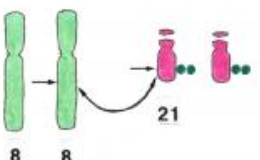

$\square$

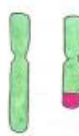

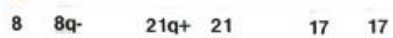

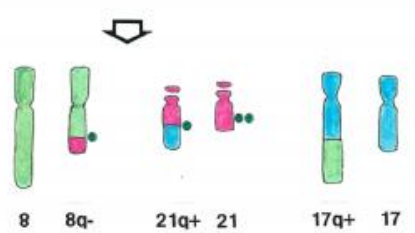

One step three way translocation
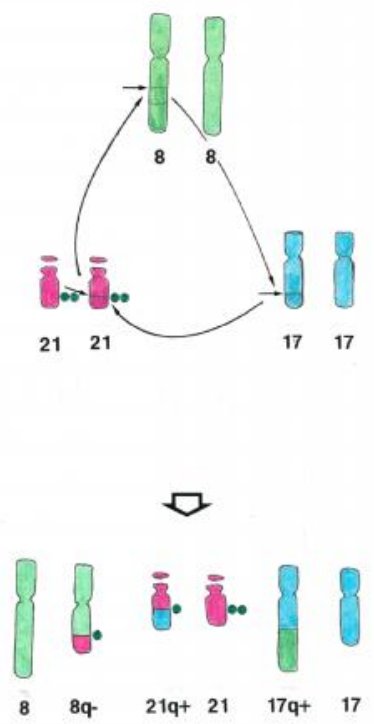

Fig.6. Scheme of two step model for formation of insertion 8;21

Case 6 ins $(21 ; 8)$
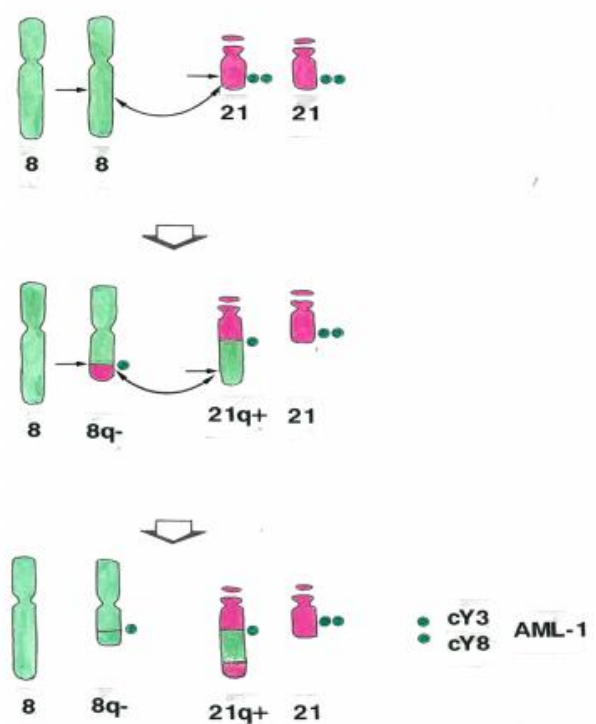

Two step translocation

Fig. 7. Summary of breakpoint sites of as 21922 chromosome aberrations [t( $8 ; 21)$ without $A M L 1$ involvement and t(16;21)]in AML, ALL and other hematological disease, which are shown in a diagram of chromosome 21.

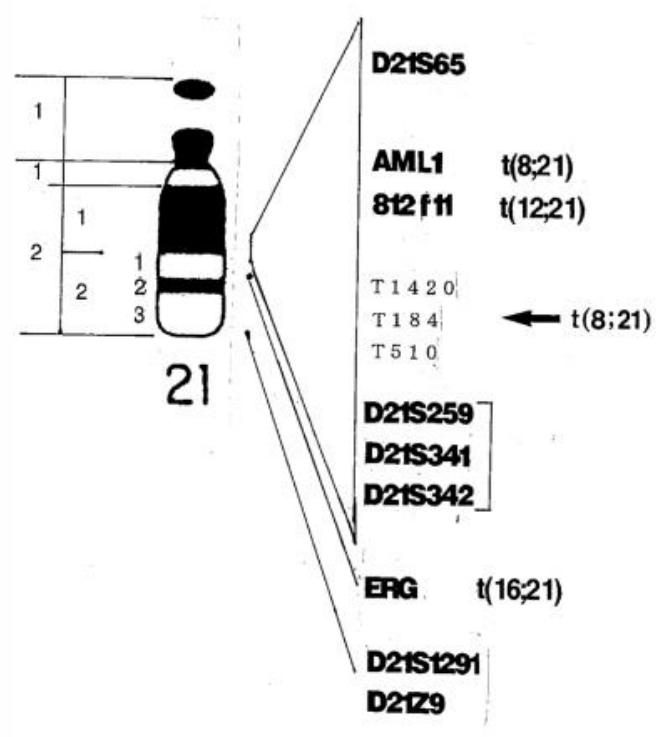


Table 4. Summary of FISH analysis using several cosmid and YAC probes in 2 AMLM2 patients with $t(8 ; 21)$, who had breakpoint proximal

\begin{tabular}{|c|c|c|c|c|c|}
\hline \multirow{4}{*}{$\begin{array}{l}\text { Case } \\
\text { No. }\end{array}$} & \multicolumn{5}{|c|}{ of $A M L 1$ gene } \\
\hline & D21 & cY3, & $812 f 2$ & T1420 & D21S259 \\
\hline & S65 & $\begin{array}{l}\text { cY8, } \\
\text { mixed } \\
(A M L 1)\end{array}$ & $\left(5^{\prime} A M L 1\right)$ & $\begin{array}{c}\text { T184 } \\
\text { single }\end{array}$ & $\begin{array}{l}\text { D21S341 } \\
\text { D21S342 } \\
\text { mixed }\end{array}$ \\
\hline & $\begin{array}{l}21 q \\
21\end{array}$ & $21 q 22$ & $21 q 22$ & $21 \mathrm{q} 22$ & 21q22.13-22.2 \\
\hline 8 & $\begin{array}{l}\text { der( } \\
21)\end{array}$ & $\operatorname{der}(21)$ & $\operatorname{der}(21)$ & $\operatorname{der}(21), \operatorname{der}(8)$ & $\operatorname{der}(8)$ \\
\hline 9 & $\begin{array}{l}\text { der( } \\
21)\end{array}$ & $\operatorname{der}(21)$ & $\operatorname{der}(21)$ & $\operatorname{der}(21), \operatorname{der}(8)$ & $\operatorname{der}(8)$ \\
\hline
\end{tabular}

According to the two step model second breakpoint might locate on the telomeric region of MTG8/ETO gene on der(8)chromosome and proximal region far from $A M L 1$ gene of der(21) chromosome.

Chromosome and FISH analyses on other hematological disease such as AML or ALL patient without AML 1 gene involvement

Thirteen myeloid and lymphoid leukemia patients who had variable abnormalities at $21 \mathrm{q} 22$ of chromosome 21 such as translocations of $t(8 ; 21), t(3 ; 21), t(17 ; 21)$ and $\mathrm{t}(16 ; 21)$, and add(21) and idic(21) were analyzed by both interphase and metaphase FISH analyses using $A M L 1$ gene probe and WCP 21 probes in order to evaluate whether breakpoint sites associated with these abnormalities were located outside of $A M L 1$ gene or not. The 13myeloid and lymphoid leukemia patients (nos.8-20 in Table 2) did not have any significantly higher splitting AML1 signals by interphase FISH, which were also confirmed by RT-PCR analysis of AML1-MTG8/ETO chimeric gene in three patients (case nos. 8,9 and 11). Percent of cells with splitting signal were significantly lower than cut-off value $(4.13 \%)$ which was previously obtained by us (Tanaka et al., 1999a,b).

Report on $\mathrm{t}(8 ; 21)$ patients without $A M L 1$ gene involvement has not been published so far except our previous case (Kawano et al., 1997). Interestingly, three patients (nos.8, 9 and 10) had typical $t(8 ; 21)$ translocation, who were diagnosed as AMLM2 transformed from MDS in one patient, and one each of AMLM4 and ALLL2. All of the three patients had breakpoints proximal of $A M L 1$ gene. Established cell line from bone marrow cells of the AMLM4 patient (case no. 8) showing CD19, CD34+ cell surface marker was used for present analyses (courtesy from Dr. Kawano S. of Tenri Hospital, Nara, Japan). The cell line established from relapse stage of $t(8 ; 21)$-positive AMLM4 case had both abnormalities of $t(8 ; 21)$ and $t(9 ; 21)$ in a same karyotype, which had gene rearrangement of $m B C R$ $A B L 1$ chimeric expression. Second MDS-AMLM2 patient (case no.9) was published previously (Kawano et al., 1997). The patient had cell surface markers of CD7+,CD19- in MDS stage and CD7-, CD19+, CD56+ in $A M L$ stage, showing typical $t(8 ; 21)$ AMLM2 , and his karyotype of main clone had two normal chromosome 8 and one $\operatorname{der}(8)$ chromosome, and one each of normal and YAC probes mapped or were performed in these two patients (case nos. 8 and 9) to identify breakpoint sites on chromosome 21 . The metaphase FISH results on these 2 leukemia patients with $t(8 ; 21)$ are summarized in Table 4. Signals of AML1 YAC probes (cY3 and $\mathrm{cY} 8$ ) and $812 \mathrm{f} 2$ located on 21q22 of der(21) chromosome, while mixture probes of D21S259, D21S341 and D21S342 mapped at 21q22.1322.2 region of chromosome 21 , which located proximal of $A M L 1$ gene and moved to $\operatorname{der}(8)$ chromosome. Metaphase FISH using each YAC probes of T1420, T184 and T510, which also locate proximal of $A M L 1$ gene, mapped in order from centromere to telomereon $21 \mathrm{q} 22$ revealed that they showed splitting signals in these two patients (case nos. 8 and 9), which indicating that their breakpoints of $t(8 ; 21)$ might be localized within the region where these probes mapped. Their splitting signals were observed between T1420 and T184 in case 8 and between T184 and T510 in case 9 by interphase and metaphase FISH. These three probes are located within approximately $0.5 \mathrm{Mb}$ region of $21 \mathrm{q} 22.11-12$ of chromosome 21. Third childhood ALL case (no.10) could be analyzes by interphase FISH only because of small amount of remained specimens. Splitting signals were only observed in more than $80 \%$ of observed cells by FISH using mixture probe of three PACs of T1420, T184 and T510, but not using mixture probes of neither AML1 (cY3 and cY8) nor D21S259, D21S341 and D21S342. These results are indicating all of the three $t(8 ; 21)$ positive leukemia patients without $A M L 1$ gene involvement might have their breakpoint sites of $t(8 ; 21)$ within the region, where these 3 PAC probes (T184, T510 and T1420) located. Precise FISH analyses revealed that the leukemic cells in patient (case no. 9) had segmental jumping translocation (SJT) of a region of chromosome 21 , in which a part of chromosome segment on chromosome 21 moved to several regions on other chromosomes (Tanaka et al., 1997, Tanaka \& Kamada, 1998). AML1 gene was involved within the common region of the SJT.

One patient (case no. 11) had typical $\mathrm{t}(8: 21)$ and had AML 1-MTG8/ETO chimeric gene expression at diagnosis stage, but the main clone having $\mathrm{t}(8 ; 21)$ was changed to another $\mathrm{t}(17 ; 21)$ translocation after chemotherapy. The $t(17 ; 21)$ leukemic cells appeared at relapse stage did not
Research article

CIndian Society for Education and Environment (iSee)
"8;21 translocation in leukemia" http://www.indjst.org
Kimio Tanaka et al. Indian J.Sci.Technol. 
have AML1 splitting signals. Metaphase FISH analysis also confirmed breakpoint located proximal site of $A M L 1$ gene. FISH analysis at diagnostic stage was not performed because remaining sample was not available. An AMLM2 patient (case no.12) showed only $2.3 \%$ splitting signals of AML1, which was less than the cut-off value $(4.13 \%)$ of $A M L 1$ probe. She was originally identified as $\mathrm{t}(3 ; 21)(\mathrm{p} 14 ; \mathrm{q} 22)$, but FISH analysis using WCP probes revealed to be complex translocation of $t(1 ; 21 ; 3)$. But the abnormality was not classical $t(3 ; 21)$ (q26;q22), which is frequently found therapy related AML and MDS because chromosome breakpoint was on 3p14, not on 3q26, where EVI1 gene mapped( Fears et al., 1996). Another patient (case no. 13), who was heavily exposed to atomic bomb radiation in Hiroshima, had $\mathrm{t}(3 ; 21)$, but the abnormality was also not classical therapy-related $t(3 ; 21)$ translocation, because her breakpoint was 3q25, not 3q26.

It is known that $\mathrm{t}(16 ; 21)$ translocation had breakpoint outside of $A M L 1$ gene (Panagopoulos et al., 1994). The three patients (nos. 14,15 and 16), who were diagnosed as AMLM2, AMLM4 and ALLL2, had very few percent of AML1 splitting signals and $t(16 ; 21)$ leukemic cells had breakpoints proximal of $A M L 1$ gene. Another two patients (case nos. 17 and 18), who were diagnosed as MDS and relapse stage of AMLM2 had add(21)(q22) abnormalities. First AMLM2 patient had both abnormalities of $t(7 ; 11)$ and $\operatorname{add}(21)(\mathrm{q} 22)$. These two patients with $\operatorname{add}(21)$ abnormalities had breakpoint also proximal region of AML1.

Last two AML patients (nos. 19 and 20) diagnosed as AML M2 and MDS-AML M2 had iso-dicentric chromosome 21q22 [idic(21)(q22)], which were published previously (Sankar et al., 1998). The breakpoints of the abnormalities in these patients were again outside of $A M L 1$ gene. The iso-dicentric abnormalities were found 3 in a metaphase in both patients, which is considered to be a kind of SJT. Common region of the SJT may be involved $A M L 1$ gene. In conclusion, interphase and metaphase FISH analysis revealed that breakpoints of 21q22 abnormalities in all 13 patients (nos.8-20) located on telomere site of $A M L 1$ gene. Three of the 13 patients had SJT, which is another mechanism of gene amplification (Tanaka \& Kamada, 2008).

\section{Discussion}

The AML1 (RUNX1/CBFA2) gene in the most frequent target of chromosomal rearrangements observed in human AML M2. These rearrangements include the commonly reported $\mathrm{t}(8 ; 21)(\mathrm{q} 22 ; \mathrm{q} 22)$ of $A M L 1-$ MTG8/ETO fusion gene and $\mathrm{t}(3 ; 21)(\mathrm{q} 26 ; \mathrm{q} 22)$ of $A M L 1-$ $E V I 1, A M L 1-E A P$ or $A M L 1-M D S 1$ fusion genes in mostly therapy related $A M L$ or MDS, and $t(12 ; 21)(p 13 ; q 22)$ of TEL/ETV6-AML1 fusion gene in B-cell childhood ALL. Breakpoints in AML1 for these fusion genes occurs in intron 6; this same intron is involved in the $t(3 ; 21)$, on the while more distal region, 5 -AML site in the $t(12 ; 21)$. Most AML1/RUNX1 related chimeric protein retains the Runt homology domain and inhibits transcriptional activity of wild-type AML1/RUNX1 in a dominant negative manner. However, the contribution of these fusion proteins to leukemogenesis remains largely unknown. Recent a publication indicates AML1/RUNX1 -MTG8/ETO fusion protein associated to deregulate proliferation and growth factor responsiveness (Peterson \& Zhang 2004; Peterson et al., 2007; Liddiard et al., 2012; Liu et al., 2012). Complex chromosome translocations have also been described in $3.4 \%$ of patients with the FAB M2 subtype of the AMLM2 with standard $\mathrm{t}(8 ; 21)$ (Groupe Francais de Cytogenetique Hematologique 1990). To date, variable and also non consisting number of chromosome was involved in the third chromosome for complex 8;21 chromosomes. Molecular biological analysis on complex 8;21 translocation cases revealed that regardless of the heterogeneity of number of third chromosome by $\mathrm{FISH}$ and RT-PCR analyses, all the breakpoints constantly located within same intron between exons 5 and 6 (de Greef et al., 1995). Insertion 8;21 abnormality is rare in AMLM2 patients (Taviaux et al.,1999; Gamerdinger et al., 2003; Specchina et al., 2004). The size of inserted segments ranged from 2.4 to $44 \mathrm{Mb}$ (Specchina et al., 2004). High resolution RNA expression analysis revealed that AML with ins $(8 ; 21)$ AMLM2 had similar whole genomic expression patters as well as $A M L 1-M T G 8 / E T O$ chimeric gene expression as that of AMLM2 patients with standard $t(8 ; 21)$, indicating that these two aberrations is biologically resemble (Rücker et al., 2011). Base on these findings $A M L 1-M T G 8 / E T O$ chimeric expression is crucial for leukemogenesis of AMLM2, independent of insertion size or any third chromosome.

Three mechanisms will be considerable to explain how complex 8;21 translocation develops, which are one step translocation, two step translocation and insertion. These one step translocation and two step translocation models are shown in a diagram (Figs.5,6). One step translocation is developed at the same time, in which a segment of chromosome 8 moves to third chromosome, and a segment of the third chromosome backed to the breakpoint end of chromosome 8, where a translocated chromosome segment is circulated. In several CML cases, which either one or two way translocation was involve could not identify. All of the cloned gene fragments from der(9), der(22) and $\operatorname{der}(\alpha)$ chromosomes ( $\alpha$ is any chromosome number for the third chromosome) by gene cloning showed fused gene consisting in each other segment derived from partner chromosomes (Morris et al., 1996; Fitzgerald \& Morris, 1999). Secondary, in two step translocation, two translocations are developed sequentially, in which second translocation between der(8)or der(21) and any number of third chromosome is developed after standard 8;21 translocation occurred. Three molecular cloning data indicated that breakpoints occurred within the same regions. Third mechanism is insertion, which was found in present two patients (nos. 6 and 7). Both of the AMLM2 patients showed normal
Research article

CIndian Society for Education and Environment (iSee)
"8;21 translocation in leukemia" http://www.indjst.org
Kimio Tanaka et al. Indian J.Sci.Technol. 
looking chromosome 8 and long sized $\operatorname{der}(21)$ chromosome in all metaphases. It seems that a segment of chromosome 8 involving MTG8/ETO gene itself inserted into $A M L 1$ gene on chromosome 21, although AML1-MTG8/ETO gene always forms on $\operatorname{der}(8)$ chromosome in standard $8 ; 21$ translocation. On the base of the FISH results with WCP 8 and WCP21 probes, and locus specific YAC and cosmid probes such as AML1, all of the seven complex 8;21 aberrations observed in AMLM2 patients(five complex $8 ; 21$ translocations and two $8 ; 21$ insertions ) could be explained to be developed by two step mechanism (Figs. 5, 6), although these were identified by FISH using limited number of locus specific probes. Present FISH analysis in the two insertion 8;21 patients revealed that insertion of MTG8/ETO gene on chromosome 8 itself inserted into $A M L 1$ gene and formed AML 1-MTG8/ETO on der(21) chromosome may be unlikely, because large chromosome segment of chromosome 8 moved to interstitial region of chromosome 21. Similarly, small size of chromosome segment of chromosome 22 involving $B C R-A B L$ chimeric gene moved to other chromosome in a CML patient (Tanaka et al., 2000).

Of course it remains unclear whether the $t(8 ; \alpha)$ and $\mathrm{t}(8 ; 21 ; \alpha)(\alpha$ is any number of third chromosome) occurred at the same time of developing standard $8 ; 21$ translocation or after the chromosomal rearrangement generating the co-localization of $A M L 1$ and MTG8/ETO. We have experienced one CML patient previously, who had both abnormalities of complex 9;22 translocation of $t(5 ; 9 ; 21)$ and standard $t(9 ; 22)$ translocation in the bone marrow cells, and the mixture of two kinds of $9 ; 22$ translocation was consistently observed in these observation dates from chronic phase and blastic crisis phases (Tanaka et al., 2001). Sequentially analyzed another two cases with CML in the both chronic and blastic crisis phases suggested that complex karyotype was acquired secondary (Tanaka et al., 2001). These results suggested a possibility that complex $8 ; 21$ translocation occurred later or soon after formation of standard $\mathrm{t}(8 ; 21)$ translocation as well as that complex translocation might be secondary developed by two step mechanism.

In addition to $\mathrm{t}(8 ; 21)$ translocation, $A M L 1$ gene is known to be involved in other about 15 recurrent translocations such

$\mathrm{t}(3 ; 21)(\mathrm{q} 26 ; \mathrm{q} 22), \mathrm{t}(1 ; 21)(\mathrm{p} 32 ; \mathrm{q} 22), \mathrm{t}(7 ; 21)(\mathrm{p} 22 ; \mathrm{q} 22)$,

$t(11 ; 21)(q 12 ; q 22), t(16 ; 21)(q 24 ; q 22)$ and so on, most of which occur more frequently in therapy-related $A M L$ and MDS than $\mathrm{t}(12 ; 21)(\mathrm{p} 12 ; \mathrm{q} 22)$ in most common childhood ALL(Slovak et al., 2002). Fusion genes formed in these21q22 translocations have been identified. Chromosome breakpoints in $A M L 1$ gene of $\mathrm{t}(3 ; 21)$, $\mathrm{t}(7 ; 21), \mathrm{t}(11 ; 21)$ and $\mathrm{t}(12 ; 21)$ were also mapped in introns 5 and 7a, respectively (Nucifora \& Rowley, 1995). Their novel fusion genes resulting from these translocations relating with AML1 play an important role in leukemogenesis. It is suggesting that such a AML1/RUNTX1 region on chromosome 21q22 has much higher recombination. The association of the therapyrelated disorders with translocation involving AML1/RUNTX1/CBFA2 was significantly higher by Fisher's exact test $(p<0.003)$ (Roulston et al., 1998). These results provide further evidence that this region of AML1/RUNTX1/CBFA2 is susceptible to breakage in cells exposed to topoisomerase II inhibitors. In vivo Topo II cleavage sites and DNase I hypersensitive sites, thus represent open chromatin region, were observed in two genomic breakpoint cluster regions on $A M L 1$ gene (Zhang et al., 2002; Zhang \& Rowley, 2006; Stricket al., 2006; Giguěre \& Hĕbert, 2011). It is generally believed that open chromatin containing active genes is more sensitive to chemical or radiation damage than compact chromatin. Topo II is a primary chromosome scaffold protein and is essential for chromosome condensation, transcription and replication as well as for apoptosis (Liu et al., 2012). Many DNase I hypersensitive sites are associated with transcriptional regulatory DNA element as scaffold attachment regions (SARs) at gene boundaries or within genes. AT-rich DNA SARs usually define the attachment sites of interphase and metaphase chromatin loops in the DNA scaffold-loop model of chromosome. A recently published report that CD19, which is a direct target of chromatin structure facilitated protein PAX5 in cells with or without $\mathrm{t}(8 ; 21)$ translocation, was frequently expressed in AML M2 with $t(8 ; 21)$, and presumed importance of progenitor-specific chromatin (Walter et al., 2010). Furthermore, there are reports on the association between an increase number of MDS patients with thrombocytopenia, bone marrow blasts, and poor overall survival and germ line mutation of AML1/ RUNTX1 deficiency (Liew \& Owen,2011), which indicating that $A M L 1 / R U N T X 1$ gene itself associates with somatically and hereditary unstable genomic events.

Variable chromosome abnormalities of 21q22 on the chromosome 21 are observed quite frequently in $A M L$ or ALL. We have experienced more than 50 AML or ALL patients with chromosome abnormalities at breakpoint site of $21 \mathrm{q} 22$ such as $t(8 ; 21), t(3 ; 21), t(17 ; 21), t(16 ; 21)$ and so on last two decades. Leukemia patients with both translocations of $t(9 ; 22)$ and $t(8 ; 21)$ in a same karyotype are observed in extremely rare frequency (Kojima et al., 1999). We have experienced only two patients of more than 1000 leukemia patients last three decades, who were diagnosed as Philadelphia chromosome-positive AML. However, molecular analysis on breakpoint sites of chromosome 21q22 in the leukemia has not been performed. Present interphase and metaphase $\mathrm{FISH}$ analyses using locus specific AML1 probe and whole painting probes in the representative 13 patients revealed that all of them had breakpoint site proximal of $A M L 1$ gene. Their identified breakpoint sites of $t(8 ; 21)$ translocation are mapped on diagram of chromosome 21 together with $t(16 ; 21)$ (Fig. 7). There is no publication 
except our previous and present reports (Kawano et al.,1996), then at(8;21) patient without $A M L 1$ gene involvement is observed extremely rare. About $60 \mathrm{AML}$ cases with $t(16 ; 21)$ have been reported to have various morphological features, mostly in $A M L F A B M 4$ or $F A B$ M5, and fewer in AMLM1, M2 and M7 (Kong et al., 1997; Sikami et al., 1999). Translocation of $t(16 ; 21)$ rarely occurs with an only $1 \%$ of AML, forming TLS/FUS-ERG fusion transcript (Kong et al., 1997). All of the patients were diagnosis as AML, mostly expressed CD56 antigen (Sikamiet al., 1999), but presently reported ALL is very rare.

Chromosomal region of $21 \mathrm{q} 22$ might have a lot of breakpoints region and might prone to acquire several chromosome aberrations. Three of the 13 patients had SJT at $21 \mathrm{q} 22$ region of chromosome 21 , which is characterize grovel genomic instability. We have recently experienced one more AML patient with idic(21) (Ikuta et al., 2011). Separate metaphase and interphase FISH analysis on two B-cell malignant lymphoma patients with add(21)(q22) revealed that they had also breakpoints telomeric of $A M L 1$ gene. We have experienced more AML or MDS patients harboring recurrent translocations associated with $21 \mathrm{q} 22$ region last two decades, which were $t(9 ; 21)(p 13 ; q 22)$ and $t(13 ; 21)(q 14 ; q 22)$ in $A M L ~ M 2$, $t(X ; 21)(p 11 ; q 22)$ in $A M L M 1, \operatorname{der}(21) t(5 ; 21)(q 11 ; q 22)$ in hypoplastic acute leukemia and $t(5 ; 21)(q 15 ; q 22)$ in MDS, but precise breakpoint sites of these chromosome aberrations were not identified by FISH analysis because of small volume of reserved samples. Several chromatin structural elements including in vivo topo II DNA cleavage sites, DNase I hypersensitive sites and SARs have been characterized for possible higher development of translocations or other type of chromosome aberrations in leukemia and other cancers at near region of $A M L 1$ /RUNX1/CBFA2 gene. Presumably, repaired DNA is subsequently reassembled into chromatin in order to allow the epigenetic information to be restored and to repackage and protect the genome (Chen \& Tyler 2008).

In conclusion, more grove chromatin change or some specific gene structure and gene function such as insulator (Gabrea et al., 2006) might form after initial chromosome translocation near initially occurred chromosome breakpoint regions, which may occur secondly translocation.

\section{Acknowledgments}

We are indebted to the following people for providing us samples and clinical information; Drs. Dohy $\mathrm{H}$. of Hiroshima Red Cross Hospital, Dr. Kimura A. of Department of Hemato-oncology, Research Institute for Radiation Biology and Medicine , Hiroshima University, Drs. Kawano S. and Miyanishi S. of Medical Inst. of Tenri Hospital, Drs. Takeshita M., Ms Ishikawa A. and Ms. Ohgami A. of Fukuoka Medical School, Dr. Sanada T. of National Kumamoto Hospital, Drs. Nakamura M. and Sadamori N. of Medical School of Nagasaki University and Dr. Araki K of Medical School of Ryukyu University.

\section{References}

1. Bennett JM, Catovsky D, Daniel M-T, Flandrin G, Galton DAG, Cralnick HR and Sultan C (1985) Proposed revised criteria for the classification of acute myeloid leukemia: A report of the French-AmericanBritish cooperative group. Ann. Intern. Med.103, 620625.

2. Calabrese G, Min T, Stuppia L, Powles R, Swansbury JG, Morizio E, Peila R, Donti E, Fioritoni G and Palka $G$ (1996) Complex chromosome translocations of standard $t(8 ; 21)$ and $t(15 ; 17)$ arise from a two-step mechanism as evidenced by fluorescence in situ hybridization analysis. Cancer Genet. Cytogenet. 91, 40-45.

3. Chen CC and Tyler J (2008) Chromatin reassembly signals the end of DNA repair. Cell Cycle. 7(24), 37923797.

4. de Greef GE, Hagemeijer A, Morgan R, Wijsman J, Hoefsloot LH, Sandberg AA and Sacchi N (1995) Identical fusion transcript associated with different breakpoints in the AML1 gene in simple and variant $\mathrm{t}(8 ; 21)$ acute myeloid leukemia. Leukemia. 9, 282-287.

5. Eguchi-Ishimae M, Eguchi M, Tanaka K, Hamamoto K, Ohki M, Ueda K and Kamada N (1998) Fluorescence in situ hybridization analysis of 12;21 translocation in Japanese childhood acute lymphocytic leukemia. Jpn. J. Cancer Res. 89, 783-788.

6. Fears $S$, Mathieu $C$, Zeleznik-Le N, Huang $S$ and Rowley JD (1996) Intergenetic splicing of MDS1 and EVI1 occurs in normal tissues as well as in myeloid leukemia and produces a new member of the PR domain family. Proc. Natl. Acad. Sci, USA. 93, 16421647.

7. Fitzgerald $\mathrm{PH}$ and Morris C (1999) Ph-negative patients with Philadelphia-positive leukemia. Blood. 78, 1078-1084.

8. Fourth Internal Workshop on Chromosomes in Luekemia 1982, (1984) Translocation (8;21)(q22;q22) in acute non lymphocytic leukemia. Cancer Genet. Cytogenet. 11, 284-287.

9. Gabrea A, Bergsagel PL and Kuehl WM (2006) Distinguishing primary and secondary trasnlocations in multiple myeloma. DNA Repair. 5, 1225-1233.

10.Gamerdinger U, Teigler-Schlegel A, Pils S, Bruch J, Viemann S, Keller M, Jauch A and Harbott J (2003) Cryptic chromosomal aberrations leading to an AML1/ETO rearrangement are frequently caused by small insertions. Genes Chrom. Cancer. 36, 261-272.

11. Giguĕre $A$ and Hĕbert J (2011) Microhomologies and topoisomerase II consensus sequences identified near the breakpoint junctions of the recurrent $\mathrm{t}(7 ; 21)(\mathrm{p} 22 ; \mathrm{q} 22)$ translocation in acute myeloid leukemia. Genes Chrom. Cancer. 50, 228-238.

12.Groupe Francais de Cytogenetique Hematologique (1990) Acute myeogenous leukemia with an 8;21 translocation: a report of 148 cases from the groups
Research article

CIndian Society for Education and Environment (iSee)
"8;21 translocation in leukemia" http://www.indjst.org
Kimio Tanaka et al. Indian J.Sci.Technol. 
Francais de Cytogenetique Hematologique. Cancer Genet.Cytogenet. 44, 169-179.

13. Ichikawa H, Hosoda F, Arai Y, Shimizu K, Ohira M and Ohki M (1993) A Not I restriction map of the entire long arm of human chromosome 21. Nature Genetics. 4, 361-366.

14.Ikuta M, Takamutsu $\mathrm{Y}$, Tanaka $\mathrm{K}$, Ishida $\mathrm{H}$, Kato J, Fujinami S, Futaya $\mathrm{Y}$, Kawashima $\mathrm{H}$ andMatsunaga $\mathrm{A}$ (2011) Several isodicentric chromosome 21s, idic(21)(q22), in acute myeloid leukemia. Nihon Rinsho Kensa Ketueki Gakkai Zasshi. 11(2), 195-201. (in Japanese)

15.ISCN 2005, An International System for Human Cytogenetic Nomenclature (2005). Shaffer LG \& Tommerrup N (ed.), also in Cytogenetics and Genome Research, Karger, Basel.

16.Kawano S, Miyanishi S, Shimizu K, Tanaka K, Okumura A, Ohki M, Kamada N and Ohno Y-I (1997) Genetic analysis of 8;21 chromosomal translocation without AML1 gene involvement in MDS-AML. Br. J. Haematol. 99, 632-640.

17. Kim H, Moon HW, Hur M, Yun YM and Lee MH (2011) Acute myelocytic leukemia with a RUNX1-RUNX1T1 $\mathrm{t}(1 ; 21 ; 8)(\mathrm{q} 21 ; \mathrm{q} 22 ; \mathrm{q} 22)$ novel variant: a case report and review of the literature. Acta Haematol. 125 (4), 237-241.

18.Kojima K, Yasukawa $M$, Ishimaru $F$, Dansako $H$, Matsuo $Y$, Kimura $Y$, Nawa $Y$, Hara M and Harada M (1999) Additional translocation(8;21)(q22;q22) in a patient with Philadelphia-positive chronic myelogenous leukemia in the blastic phase. Br. J. Heamatol. 106, 720-722.

19.Kong X-T, Ida K, Ichikawa H, Shimizu K, Ohki M, Maseki N, Kaneko Y, Sako M, Konbayashi Y, Tojou A, Miura I, Kakuda H, Funabiki T, Horibe K, Hamaguchi $\mathrm{H}$, Akiyama $\mathrm{Y}$, Besso E, Yanagisawa M and Hayashi Y (1997) Consistent detection of TLS/FUS/ERG chimeric transcripts in acute myeloid leukemia with $\mathrm{t}(16 ; 21)(\mathrm{p} 11 ; \mathrm{q} 22)$ and identification of anovel transcript. Blood. 90, 1192-1999.

20.Kozu T, Miyoshi H, Shimuzu K, Maseki N, Kaneko Y, Asou H, Kamada N and Ohki M (1993) Junctions of the AML1/MTG8(ETO) fusion are constant in $t(8 ; 21)$ acute myelocytic leukemia detected by reverse transcription polymerase chain reaction. Blood. 82(4), 1270-1276.

21.Liddiard K, Burnett AK, Darley RL and Tonks A (2012) RUNX1-ETO deregulates the proliferation and growth factor responsiveness of human hematopoietic progenitor cells downstream of the myeloid transcription factor, MYCT1. Leukemia. 26, 177-179.

22. Liew F and Owen CI (2011) Familial myelodyspastic syndrome - a review of the literature. Hematologica. 96(10), 1536-1542.

23. Liu J, Xing $\mathrm{H}$, Chen $\mathrm{Y}$, Wang $\mathrm{L}$, Wang $\mathrm{D}$, Rao Q, Tang K, Tian Z, He K, Wang M and Wang J (2012) PIG7, transactivated by $A M L 1$, promotes apoptosis and
Vol. 5 No. 3 (Mar 2012)

ISSN: 0974- 6846

differentiation of leukemia cells with AML1-ETO fusion gene. Leukemia. 26, 117-126.

24. Miyoshi H, Kozu T, Shimizu K, Enomoto K, Maseki N, Kaneko Y, Kamada N and Ohki M (1993) The t(8;21) translocation in acute myeloid leukemia results in production of an AML1-MTG8 fusion transcript. EMBO J. 12, 2715-2721.

25. Morris C, Jeffs A, Smoty T, McDonald M, Board P, Kennedy $M$ and Fitzgerald $P$ (1996) BCR gene recombines with genomically distinct sites on band $11 \mathrm{Q} 23$ in complex BCR-ABL translocations of chronic myeloid leukemia. Oncogene. 12, 677-685.

26. Nucifora G and Rowley JD (1995) AML1 and the 8;21 translocations in acute and chronic myeloid leukemia. Blood. 86(1), 1-14.

27.Panagopoulos $I$, Aman $P$, Fioretos $T$, Höglund $M$, Jphamsson B, Mandahl N, Heim S, Behrendz $M$ and Mitelman F (1994) Fusion of the FUS gene with ERG in acute myeloid leukemia with $t(16 ; 21)(p 11 ; q 22)$. Genes Chrom. Cancer. 11(4), 256-262.

28.Peterson L and Zhang D-Er (2004) The 8;21 translocation in leukemogenesis. Oncogene. 23, 4255-4262.

29.Peterson LF, Boyapati A, Ahn EY, Okumura AJ, Lo MC, Yan $M$ and Zhang DE (2007) Acute myeloid leukemia with the 8q22:21q22 translocation: secondary mutational events and alternative $t(8 ; 21)$ transcripts. Blood 110(3), 799-805.

30.Roulston D, Espinosa T 3rd, Nucifora G, Larson RA, Le Beau MM and Rowley JD (1998) CBFA2 (AML1) translocations with novel partner chromosomes in myeloid leukemias: association with prior therapy. Blood. 92(8), 2879-2885.

31.Rücker FG, Bulllinger L, Gribov A, Sill M, Schlenk RF, Lichter P, Döhner H and Döner K (2011) Molecular characterization of $A M L$ with ins(21;8)(q22;q22q22) reveals similarity to $\mathrm{t}(8 ; 21)$ AML. Genes Chrom. Cancer. 50, 51-58.

32. Sakurai M, Sasaki M, Kamada N, Okada M, Oshimura $M$, Ishihara $T$ and Shiraishi $Y$ (1982) A summary of cytogenetic , morphologic, and clinical data on $\mathrm{t}(8 \mathrm{q}-$; $21 \mathrm{q}+)$ and $\mathrm{t}(15 \mathrm{q}+; 17 \mathrm{q}-)$ translocation leukemia in Japan. Cancer Genet. Cytogenet. 7(1), 59-65.

33.Sankar M, Tanaka K, Arif M, Shintani T, Kumaravel TS, Kyo T, Dohy H and Kamada N (1998) Isodicentric chromosome 21: a novel aberration in acute myeloid leukemia. Cancer Genet. Cytogenet. 107, 69-72.

34. Shikami M, Miwa H, Nishi K, Takahashi T, Shiku H, Tsutani H, Oka K, Hamaguchi H, Kyo T, Tanaka K, Kamada N and Kita K (1999) Myeloid differentiation antigen and cytokine receptor $\alpha$ expression on acute myelocytic leukemia cells with $t(16 ; 21)(p 11 ; q 22)$ : frequent expression of CD56 and interleukin-2 receptor achain. Br. J. Haematol. 105, 711-719.

35. Slovak ML, Bedell V, Popplewell L, Arber DA, Schoch C and Slater R (2002) 21q22 balanced chromosome aberrations in therapy-related hematopietic disorders:
Research article

CIndian Society for Education and Environment (iSee)
"8;21 translocation in leukemia" http://www.indjst.org
Kimio Tanaka et al. Indian J.Sci.Technol. 
report from an international workshop. Genes Chrom., Cancer. 33(4), 379-394.

36. Specchia G, Albano F, Anelli L, Zagaria A, Liso A, La Starza R, Mancini M, Sebastio L, Giugliano E, Saglio $\mathrm{G}$, Liso $\mathrm{V}$ and Rocchi M (2004) Insertions generating the $5^{\prime} R U N X A / 3^{\prime} C B F A T 1$ gene in acute myeloid leukemia cases show variable breakpoints. Genes Chrom. Cancer. 41, 86-91.

37. Strick $\mathrm{R}$, Zhang $\mathrm{Y}$, Emmanuel $\mathrm{N}$ and Strissel $\mathrm{PL}$ (2006) Common chromatin structures at breakpoint cluster region may lead to chromosomal translocations found in chronic and acute leukemias. Hum. Genet. 119(5), 479-495.

38. Tanaka K, Arif M, Eguchi M, Kyo T, Dohy $\mathrm{H}$ and Kamada N (1997) Frequent jumping translocations of chromosome segments involving the $A B L$ oncogene alone or in combination with CD3-MLL gene in secondary leukemia. Blood, 89, 596-600.

39. Tanaka K and Kamada N (1998) Segmental jumping translocation in leukemia and lymphoma with a highly complex karyotype. Leukemia \& Lymphoma. 29, 563575.

40.Tanaka K, Arif M, Asou H, Shimizu K, Ohki M, Kyo T, Dohy H and Kamada N (1999a) Detection of translocation $8 ; 21$ on interphase cells from acute myelocytic leukemia by fluorescence in situ hybridization and its clinical application. Cancer Genet. Cytogenet. 113, 29-35.

41.Tanaka K, Arif M, Eguchi M, Shintani T, Kumaravel TS, Asaoku H, Kyo T, Dohy H and Kamada N (1999b) Interphase fluorescence in situ hybridization overcomes pitfalls of G-banding analysis with special reference to under estimation of chromosomal aberration rates. Cancer Genet. Cytogenet. 115, 3238.

42. Tanaka K, Arif M, Kyo T, Dohy $\mathrm{H}$ and Kamada $\mathrm{N}$ (2000) Transposition of duplicated chromosomal segment involving fused $B C R-A B L$ gene or $A B L$ oncogene alone in chronic myelocytic leukemia and $\mathrm{Ph}$ chromosome-positive acute leukemia with complex karyotypes. Cancer Genet. Cytogenet. 119, 8-14.

43. Tanaka K, Minamihisamatsu M, Yagi S, Kyo T, Dohy $\mathrm{H}$ and Kamada N (2001) Two step mechanism for formation of complex 9;22 chromosome translocation in chronic myeloid leukemia, detected by fluorescence in situ hybridization. Exp. Oncol. 23, 29-38.

44.Taviaux S, Brunel V, Dupont M, Fernandez F, Ferraz C, Carbuccia N, Sainty D, Demaille J, Birg F and Lafage-Pochitaloff $M$ (1999) Simple variant $t(8 ; 21)$ acute myeloid leukemias harbor insertions of the AML 1 or ETO genes. Genes Chrom. Cancer. 24, 165171.

45. Vieira L, Oliveira $\mathrm{V}$, Ambrósio AP,Hagemeijer BM and Boavida MG (2001) Translocation $(8 ; 17 ; 15 ; 21)(q 22 ; q 23 ; q 15 ; q 22)$ in acute myeloid leukemia (M2): a four-way variant of $\mathrm{t}(8 ; 21)$. Cancer Genet. Cytogenet. 128(2), 104-107.
Vol. 5 No. 3 (Mar 2012)

ISSN: 0974- 6846

46. Walter K, Cockerill PN, Barlow R, Clarke D, Hoogenkamp M, Follows GA, Richards J, Cullen MJ, Bonifer $\mathrm{C}$ and Tagoh $\mathrm{H}$ (2010) Aberrant expression of CD19 in AML with $t(8 ; 21)$ involves a poised chromatin structure and PAX5. Oncogene. 29, 2927-2937.

47.WHO Classification of Tumours 2007; (2008) WHO Classification of Tumours of Heamatopoietic and Lymphoid Tissues, Swerdlow SH, Campo E, Harris N, Jaffe ES, Pileri SAH, Stein J, Thiele $J$ and Vardiman JW (Eds.), International Agency for Research on Cancer, Lyon.

48.Zhang Y, Strissel P, Strick R, Chen J, Nucifora G, Beau MN, Larson RA and Rowley JD (2002) Genomic DNA breakpoints in AML1/RUNX1 and ETO cluster with topoisomerase II DNA cleavage and DNAase I hypersensitive sites in $\mathrm{t}(8 ; 21)$ leukemia. Proc. Natl. Acad. Sci., USA, 99(5), 3070-3075.

49.Zhang $Y$ and Rowley JD (2006) Chromatin structural elements and chromosomal translocations in leukemia. DNA Repair, 5, 1282-1297.
Kimio Tanaka et al. Indian J.Sci.Technol. 